\title{
Discovery of a mcl-PHA with unexpected biotechnical properties: the marine environment of French Polynesia as a source for PHA-producing bacteria
}

\author{
P. Wecker ${ }^{1 *}$, X. Moppert $^{2+}$, C. Simon-Colin ${ }^{3+}$, B. Costa $^{2}$ and V. Berteaux-Lecellier ${ }^{1}$
}

\begin{abstract}
A library of microorganisms originating from various marine environments in French Polynesia was screened for polyhydroxyalkanoate producing bacteria. No significant connection was found between the geo-ecological source of bacteria and their ability to produce polyhydroxyalkanoate. A bacterial strain designated as Enterobacter FAK 1384 was isolated from a shark jaw. When grown on coprah oil, this bacterium produces a PHA constituting of $62 \mathrm{~mol} \%$ 3-hydroxydecanoate and lower amount of $12 \mathrm{~mol} \%$ 3-hydroxydodecenoate and of $7.6 \mathrm{~mol} \%$ 3-hydroxydodecanoate. These interesting properties make this mcl-PHA a good candidate for further exploitations in many industrial sectors, as in film and coating manufacturing, as well as for biomedical applications.
\end{abstract}

Keywords: Polyhydroxyalkanoate, Marine biotechnology, Bacterial diversity, French Polynesia, Fermentation

\section{Introduction}

Microorganisms are widely recognized as a source of novel enzymes, biocatalysts and bioactive compounds, as well as biomaterials. Until recently, marine microorganism diversity was quite neglected in industrial processes in comparison to terrestrial species (Imhoff et al. 2011). In the last years, biotechnological interest in the exploitation of marine environments has been increasing and scientific literature is steadily producing new discoveries of bioactive marine metabolites (Imhoff et al. 2011). In particular, unusual environments with extreme conditions are a natural treasure chest for innovative bioactive molecules (Ferrer et al. 2005). Among these are bacterial biopolymers, and more particularly polyhydroxyalkanoates (PHA), which are biopolyesters produced by many microorganisms as intracellular storage material. It is noteworthy that their monomeric composition

\footnotetext{
*Correspondence: wecker.pat@gmail.com

${ }^{+} X$. Moppert and C. Simon-Colin contributed equally to this work

${ }^{1}$ LabEX Corail, USR3278 CNRS-EPHE-UPVD CRIOBE, BP1013, Papetoai,

Moorea, French Polynesia

Full list of author information is available at the end of the article
}

varies depending on the host and on the available carbon source. In addition, PHA comprise a large class of polyester. They can be separated into three groups, depending on the number of carbons atoms in the monomeric units: short-chain-length, medium-chain-length and long-chain-length PHA. The short-chain-length PHA (scl-PHA) are ubiquitous. They contain primarily 3-hydroxybutyrate $(3 \mathrm{HB})$ units and show limits in their mechanical properties (Hazer and Steinbuechel 2007; Kim do et al. 2007; Samrot et al. 2011). In contrast, medium-chain-length PHA (mcl-PHA) are synthetized by only a few bacteria species belonging to four to five genera. The polymers produced consists mainly of 3-hydroxyoctanoate $(3 \mathrm{HO})$ and 3-hydroxydecanoate (3HD), and appear to be much more elastomeric and resistant (Solaiman et al. 2000; Verlinden et al. 2007; Samrot et al. 2011; Kabilan et al. 2012). The commercial processes for PHA production go way back into the 1960s. In addition, molecular genetic studies give valuable insights into the regulation of PHA formation since the 1990s (Madison and Huisman 1999). Biodegradable PHA substitute more and more petrochemical plastics due to their physical and structural properties (Rawte

\section{Springer}


and Mavinkurve 2002). Unfortunately, the production costs remain the economical limitation. To achieve a cost-effective PHA production scheme, the isolation of new bacterial strains able to utilize inexpensive carbon sources has become a focus of particular interest (González-García et al. 2008).

The still largely unexploited marine environment specifically provides a new research area to isolate new microorganisms (Table 1). French Polynesia is a large territory, consisting of 118 islands forming five archipelagos, with a landmass of only $3500 \mathrm{~km}^{2}$ scattered over 5.5 million $\mathrm{km}^{2}$ of ocean. Polynesia has some particularities in this field owing to its geographical position and the presence of specific extreme ecosystems, such as microbial mats called «kopara mats/ponds» (Richert et al. 2005), uninhabited volcanic islands, hot springs, etc. The taxonomic inventory of the Polynesian island groups is still limited to the main islands of the Society, Tuamotu and Austral archipelagos, due to their geographical location (Lozouet et al. 2004). Only the major groups-corals, fishes, molluscs, echinoderms and algae-have received particular attention in the last years; knowledge of the other invertebrate groups and especially bacteria is still fragmentary, except the all-taxon microbial inventory of one Polynesian coral reef system (McCliment et al. 2012). This lack of knowledge and those different types of ecosystems make the marine environment of French Polynesia very interesting for biotechnological investigations, as is reflected already in various publications (Guezennec et al. 2011; Raguénès et al. 2004; Richert et al. 2005; Simon-Colin et al. 2008a, b, c, 2009).

Therefore, the aim of this study was the screening of a bacterial library originating from the marine biodiversity around French Polynesia for promising PHA-producing microorganisms and to get hints about geo-ecological preferences. In this study, we present a novel mcl-PHA with interesting mechanical and physical structural properties produced by a new strain Enterobacter sp. FAK 1384, isolated from a shark jaw (Carcharhinus melanopterus) nearby Fakarava Island (Tuamotu, French Polynesia).

\section{Material and methods \\ Collection, isolation, cultivation and phylogenetic identification of PHA-producing bacteria}

Since 2001, samples were collected from different geomorphological places over four of the five archipelagos of French Polynesia, which include marine sediment, marine animals, microbial mats, microbial films and the water column. Each sample was placed in a Zobell medium overnight. The resulting colonies were isolated and purified on Zobell marine agar medium using serial dilution technique. The plates were maintained in aerobic condition at $32{ }^{\circ} \mathrm{C}$ for $24-48 \mathrm{~h}$. Each pure isolate was then cultivated and placed into a $\mathrm{Nunc}^{\circledR}$ cryotube at minus $80^{\circ} \mathrm{C}$ with glycerol (20\%) as cryoprotector.

Screening of marine bacterial PHA producers was performed in nitrogen-free Zobell medium enriched

Table 1 Selection of published articles dealing with PHA-producing bacteria from the marine environment

\begin{tabular}{|c|c|c|c|}
\hline Source & Locations & Biopolymer & Isolates (References) \\
\hline Marine sediment & Pakistan & $\mathrm{mcl}-\mathrm{PHA}$ & Pseudomonas sp. CMG607w (Jamil et al. 2007) \\
\hline Marine sediment & & $\mathrm{PHB}$ & Vibrio spp. (Chien et al. 2007) \\
\hline Decaying sea marsh grass & USA & $\mathrm{PHA}$ & $\begin{array}{l}\text { Saccharophagus degradans ATCC } 42961 \text { (González-García et al. } \\
\text { 2008) }\end{array}$ \\
\hline Kopara mats & French Polynesia & $\mathrm{mcl}-\mathrm{PHA}$ & $\begin{array}{l}\text { Pseudomonas guezennei sp. nov. (Simon-Colin et al. 2008a) } \\
\text { P. raguenesii sp. nov. (Simon-Colin et al. 2009) } \\
\text { P. guezennei biovar (Simon-Colin et al. 2008c) }\end{array}$ \\
\hline Deep-sea hydrothermal vent shrimps & Mid-Atlantic Ridge & $\mathrm{PHA}$ & Halomonas profundus sp. nov. (Simon-Colin et al. 2008b) \\
\hline Soil, marine mangrove sediments, back and sea water & India & $\mathrm{PHB}$ & Vibrio sp. MK4 (Arun et al. 2009) \\
\hline Sea water & India & $\mathrm{PHB}$ & H. hydrothermalis SM-P-3M (Shrivastav et al. 2010b) \\
\hline Sea water & India & $\mathrm{PHA}$ & Spirulina subsalsa (Shrivastav et al. 2010a) \\
\hline Seawater & Japan & $\mathrm{PHA}$ & Vibrio sp. KN01 (Numata and Doi 2012) \\
\hline Contamination in stock culture on marine agar plate & & $\mathrm{PHA}$ & Bacillus sp. (Sawant et al. 2014) \\
\hline
\end{tabular}


with glucose at $20 \mathrm{~g} / \mathrm{L}$. The Nile Red coloration method (Spiekermann et al. 1999) and the Sudan Black staining method (Schlegel et al. 1970) were used together to reveal the lipophilic compounds of PHA-producing bacteria. Pure isolates containing lipophilic inclusions were identified based on microscopy and by sequencing partial sequences of their 16SrRNA. Cultures were sent to Macrogen (http://www.macrogen.com) for DNA isolation and sequencing. The results were compared with the $16 \mathrm{~S}$ rRNA sequence available in public nucleotide databases at the National Center for Biotechnology Information (NCBI) by using its World Wide Web site (http://www. ncbi.nlm.nih.gov) and the basic local alignment search tool (BLAST) algorithm (Altschul et al. 1990). Multiple sequence alignment and phylogenic analysis were performed by the neighbour-joining (NJ) method embedded in the Mega 5 software (Tamura et al. 2011). The sequence of the 16S rRNA encoding gene of strain FAK 1384 was determined and deposited to GenBank [GenBank: KJ499995].

\section{PHA production}

Production of PHA polymers was accomplished in two steps. The first one consisted of the biomass production in rich marine medium. The PHA production took place in the second step, in a nitrogen-free medium with glucose or coprah oil as carbon source. Both steps were performed in shake flask cultures $(250 \mathrm{~mL})$. The growth step took place for $16 \mathrm{~h}$ at $32{ }^{\circ} \mathrm{C}$ and $250 \mathrm{rpm}$ agitation, in a rich medium (peptone $8 \mathrm{~g} / \mathrm{L}$, yeast extract $2 \mathrm{~g} / \mathrm{L}$, glucose $10 \mathrm{~g} / \mathrm{L}$ and synthetic sea salt $10-30 \mathrm{~g} / \mathrm{L}$ according to the strain). The medium was then centrifuged $(8000 \times g$ for $10 \mathrm{~min})$ and the cell pellets were transferred into another flask containing sea salt $(10-30 \mathrm{~g} / \mathrm{L})$ and glucose or coprah oil under the same conditions. After $48 \mathrm{~h}$, cells were centrifuged (10 min at 20,000 $\times g$ ) and cell pellets were lyophilized.

Strain designated as FAK 1384 showed interesting PHA production in flask and was further cultivated in a $5 \mathrm{~L}$ bioreactor (Sartorius, Biostat A plus). Temperature was maintained at $32{ }^{\circ} \mathrm{C}, \mathrm{pH}$ at 7.6 by automatic addition of $2 \mathrm{~mol} / \mathrm{L} \mathrm{NaOH}$ and dissolved $\mathrm{O}_{2}$ at $60 \%$. All other parameters were similar to those in flasks cultures.

\section{FAK 1384 PHA extraction and characterization}

Lyophilized cell pellets were ground in a mortar and the resulting powder was extracted with chloroform for $4 \mathrm{~h}$ at $50{ }^{\circ} \mathrm{C}$. The PHA-containing chloroform phase was concentrated and extracted once with water to remove residual solid particles. The organic phase was evaporated to dryness and the resulting crude extract preserved for further analyses. Purified PHA were obtained by repeated precipitations in 10 volumes of cold methanol, and analysed by Fourier transform infra red (FTIR), nuclear magnetic resonance (NMR), gas chromatography mass spectrometry (GC-MS) and differential scanning calorimetry (DSC) as previously described in SimonColin et al. (2008c).

\section{Results}

\section{Screening for promising isolates and their origin of distribution}

Out of the 760 bacterial isolates from different biological habitats (marine sediment and animals, microbial mats and films, and water column) collected around the four island groups of French Polynesia (Tuamotu, Society, Austral and Marquesas) (Table 2), 95 showed strong fluorescence under UV light when grown on Zobell media plates containing Nile red. All 95 selected isolates were confirmed PHA positive through Sudan Black staining. The results of the multiple correspondence analysis showed a very slight tendency that PHA-producing bacteria are more often found in the water column of the Society and Austral islands, respectively, on microbial mats on the Tuamotu (Additional file 1: Fig. S1). Nevertheless, there is no significant connection between the geo-ecological source and the ability of PHA-production in French Polynesia.

\section{Confirmation of PHA production}

70 out of these 95 promising isolates were placed in shake flask cultures for PHA production. Significant (>15\%) PHA production ability of these strains was confirmed

\section{Table 2 Number of isolates per archipelago and source}

\begin{tabular}{lllllll}
\hline Archipelagos & \multicolumn{2}{l}{ Microbial } & & & Marine & Water column \\
\cline { 2 - 3 } & Mats & Film & & Sediment & Animals & \\
\hline Society & $38(2)$ & $37(1)$ & $8(-)$ & $12(1)$ & $275(48)$ \\
Tuamotu & $75(17)$ & $47(7)$ & $32(3)$ & $26(2)$ & $35(3)$ \\
Austral & $10(-)$ & $9(-)$ & $2(-)$ & $5(-)$ & $53(11)$ \\
Marquesas' & - & $1(-)$ & - & - & - \\
\hline
\end{tabular}

Number in brackets ( ) indicates isolates that were tested positive for both the Nile Red and Sudan black coloration test 
for 25 isolates (Additional file 1: Table S1). Strain FAK 1384 appeared to be one of the most promising and interesting with a PHA content around $33 \%$ cell dry weight (Additional file 1: Table S1). The resulting mcl-PHA polymer showed a good elasticity compared to other mcl-PHA currently studied in the lab (Moppert personal communication).

\section{Strain identification}

On the basis of its phylogenetic analysis, strain FAK 1384 belongs to Enterobacter sp. (Additional file 1: Fig S2). The isolate Enterobacter sp. FAK 1384 has been deposited to the Collection Nationale de Culture de Microorganisms (CNCM I-4601) (Institute Pasteur, Paris, France).

\section{PHA characterization}

PHA synthesized by strain FAK 1384 using coprah oil as carbon substrate was purified and characterized by FTIR,
DSC, NMR and GCMS as described by Simon-Colin et al. 2008c. FTIR spectra and the signals of the ${ }^{1} \mathrm{H}$ NMR spectrum show the typical characters of a mcl-PHA (Figs. 1, 2). The existence of double bound can be distinguished by additional signals around 2, 2.3 and $5.3 \mathrm{ppm}$ in ${ }^{1} \mathrm{H}$ NMR spectrum (Simon-Colin et al. 2008c).

The cristallinity index was 0.26 , which indicates a quite amorphous polymer. This result was confirmed by DSC (Fig. 3) analysis showing a melting point peak (Tm) at $47{ }^{\circ} \mathrm{C}$ with a heat of fusion $\Delta \mathrm{H}$ of $13.8 \mathrm{~J} / \mathrm{g}$, and a glass transition temperature $(\mathrm{Tg})$ of $-47^{\circ} \mathrm{C}$.

GC-MS analysis of TMSi methyl esters derivatives of PHA (Fig. 4) determinated an interesting monomer composition, containing $62 \mathrm{~mol} \%$ 3-hydroxydecanoate (3HD), $18 \mathrm{~mol} \%$ 3-hydroxyoctanoate (3HO), $12 \mathrm{~mol} \%$ 3-hydroxydodecenoate (3HDDe), $7.6 \mathrm{~mol} \%$ 3-hydroxydodecanoate (3HDD) and low fractions of $0.3 \mathrm{~mol} \mathrm{\%}$ 3-hydroxyhexanoate (3HHx) and $1.3 \mathrm{~mol} \%$

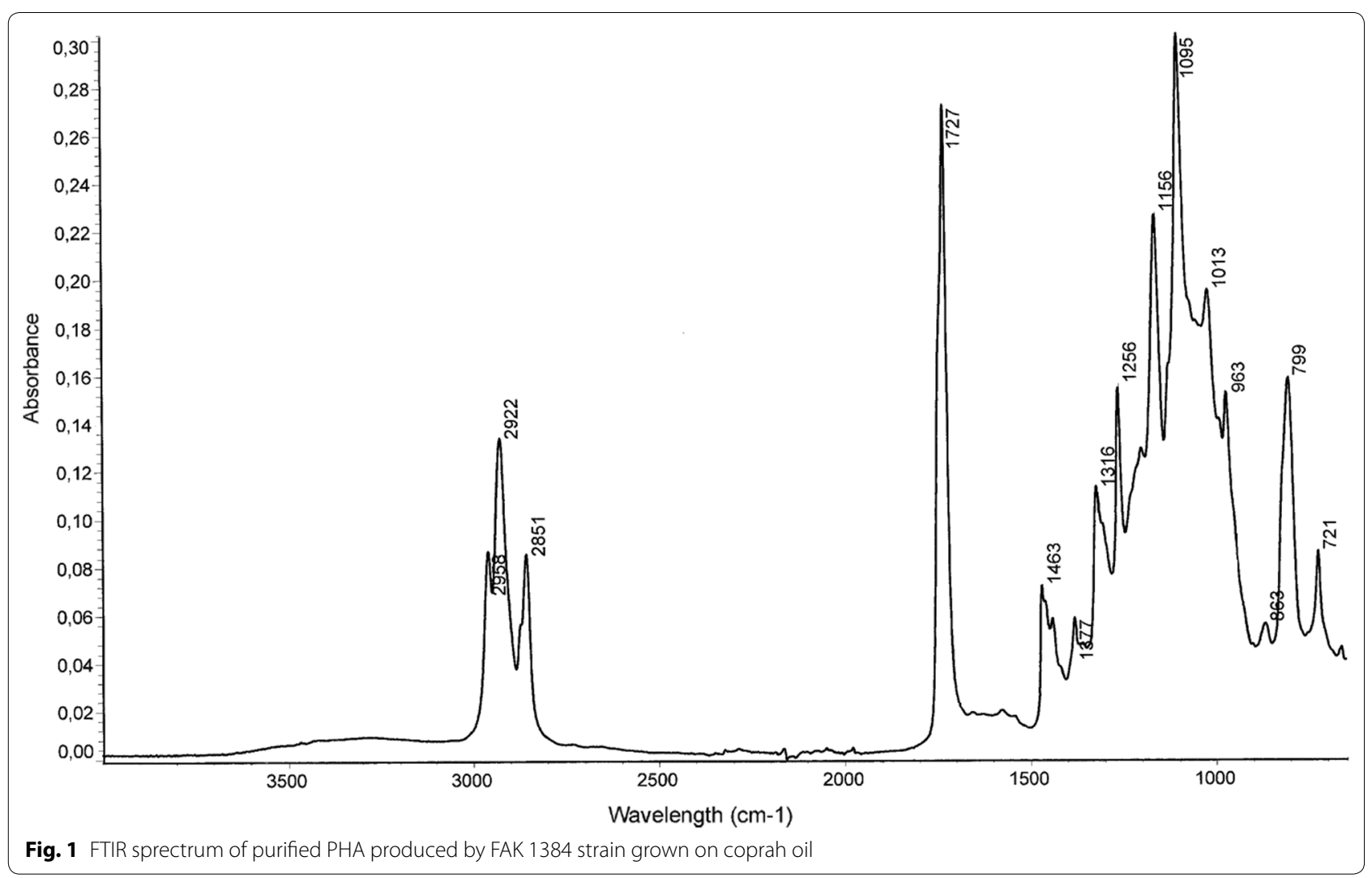




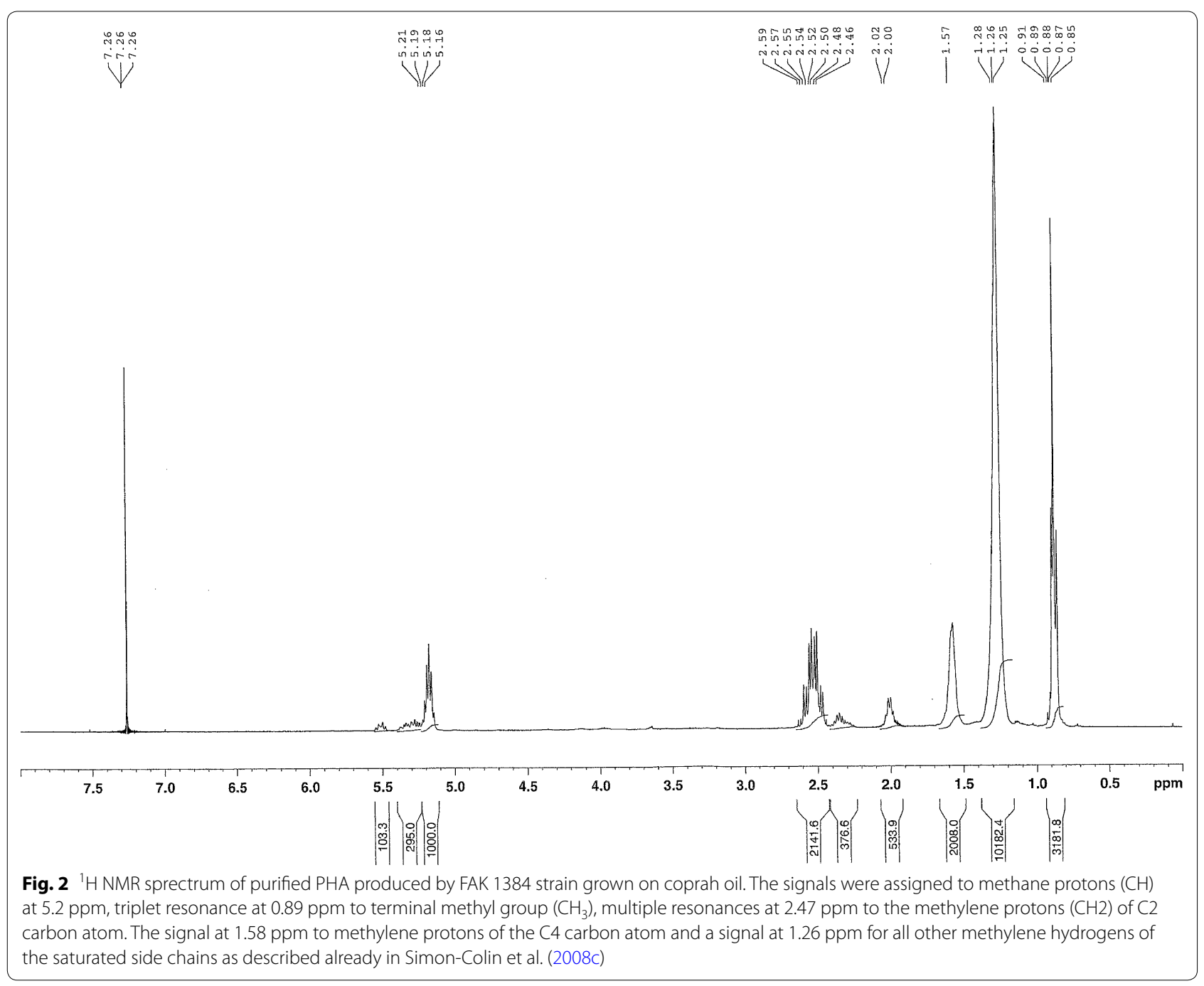

of 3-hydroxytetradecanoate (3HTD). The presence of unsaturation can be deduced from the molecular weight of the fragment at $m / z[\mathrm{M}-15]$ which is 2amu less than that of the corresponding saturated monomer, and from the weak intensity ratio of the peak at $m / z[M-15]$ to the base peak (Fig. 5).

\section{Discussion}

$12 \%$ of the 760 bacterial isolates were confirmed for PHA positive by two coloration methods. Shake flask culturing revealed a significant level of PHA production for 25 isolates (Additional file 1: Table S1). The here presented isolated FAK1384 displayed very interesting physical parameters. The phylogenetical analysis showed that it belongs to Enterobacter sp. To date, according to our state of knowledge, they are only four publications dealing with PHA-producing Enterobacter strains (Chen et al. 2010; Samrot et al. 2011; Arumugam et al. 2014; Naheed and Jamil 2014). All of them deal with isolates from a terrestrial origin and only Enterobacter cloacae SU-1 produces mcl-PHA when grown on glucose or lactose (Samrot et al. 2011). Bacterial strain FAK 1384 was 


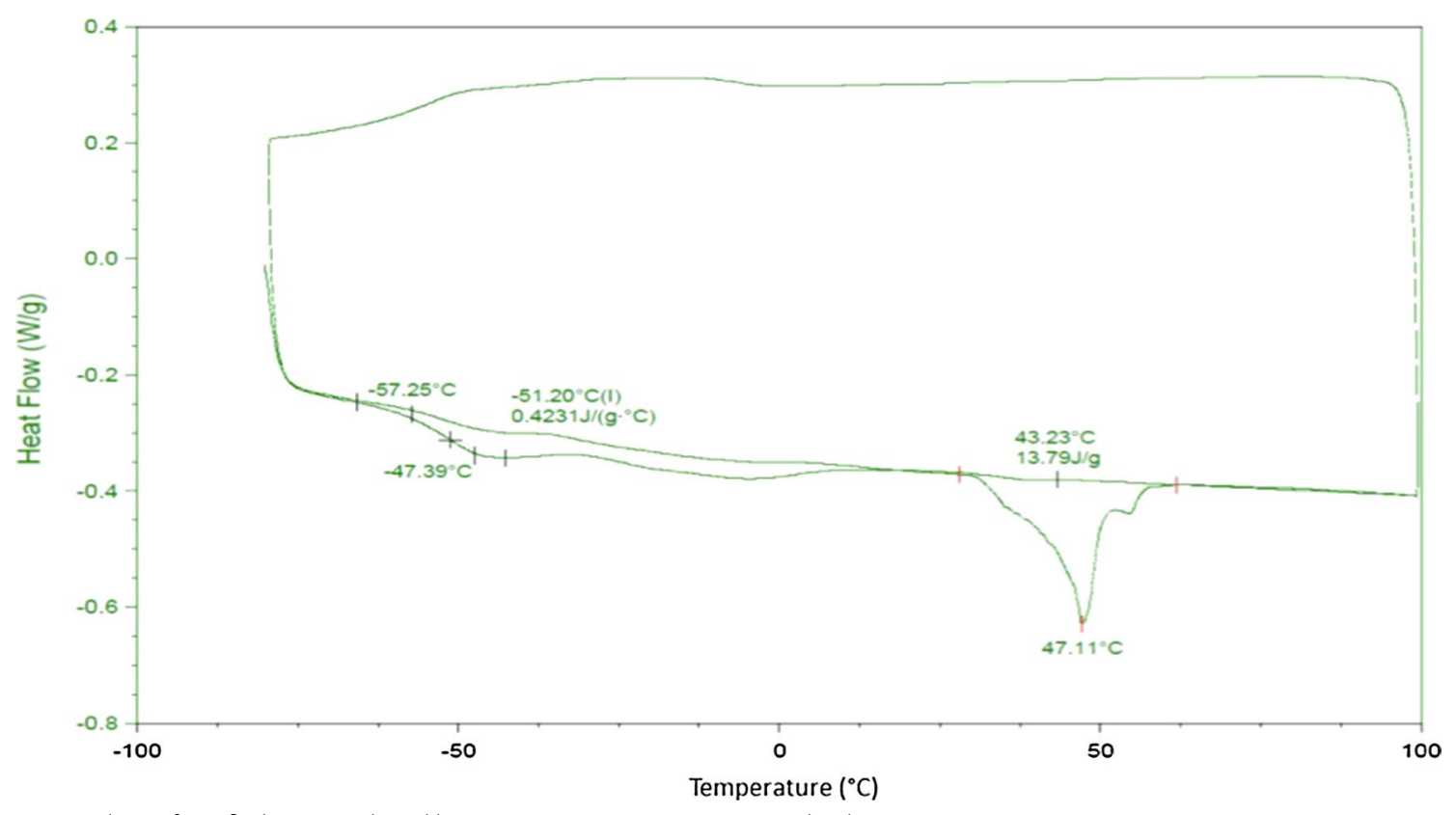

Fig. 3 DSC analysis of purified PHA produced by FAK 1384 strain grown on coprah oil

isolated from a shark jaw (Carcharhinus melanopterus) nearby Fakarava Island (Tuamotu, French Polynesia). If the isolate belongs to the bacterial community of the jaw or was taken up through the water column or with the food is not clear and needs to be investigated in the future.

However, the mcl-PHA composition is quite remarkable with a significant amount of 3-hydroxydecanoate (3HD $62 \mathrm{~mol} \%$ ), and a lower amount of 3-hydroxydodecenoate (3HDDe $12 \mathrm{~mol} \%$ ) and 3-hydroxydodecanoate (3HDD $7.6 \mathrm{~mol} \%$ ). The predomination of 3HO and 3HD is well known for various Pseudomonas species, independent of their carbon source (and reference within), whereas for the only further published mcl-PHA producing Enterobacter cloacae SU-1 grown on glucose or lactose, the main monomers are $3 \mathrm{HO}$ and $3 \mathrm{HHX}$.
The composition of the mcl-PHA produced by FAK 1384 induces a better elasticity and a greater elongation before breaking (Hazer and Steinbuechel 2007; Rai et al. 2011). Particularly outstanding is the presence of an unsaturation in the 3-hydroxydodecenoate monomer (3HDDe). Latter represents a suitable site for chemical modifications such as chlorination or cross-linking (Arkin et al. 2000; Dufresne et al. 2001; Hazer and Steinbuechel 2007). These chemical modifications increase performances of the polymer in large application domain, e.g., coating and film manufacturing (Asrar and D'haene 1999), nucleus coating for pearl culture (Bachere et al. 2011; Guezennec et al. 2011) and in the biomedical area, such as implant material drug delivery, or tissue engineering (Hazer and Steinbuechel 2007; Chen et al. 2010; Rai et al. 2011). 


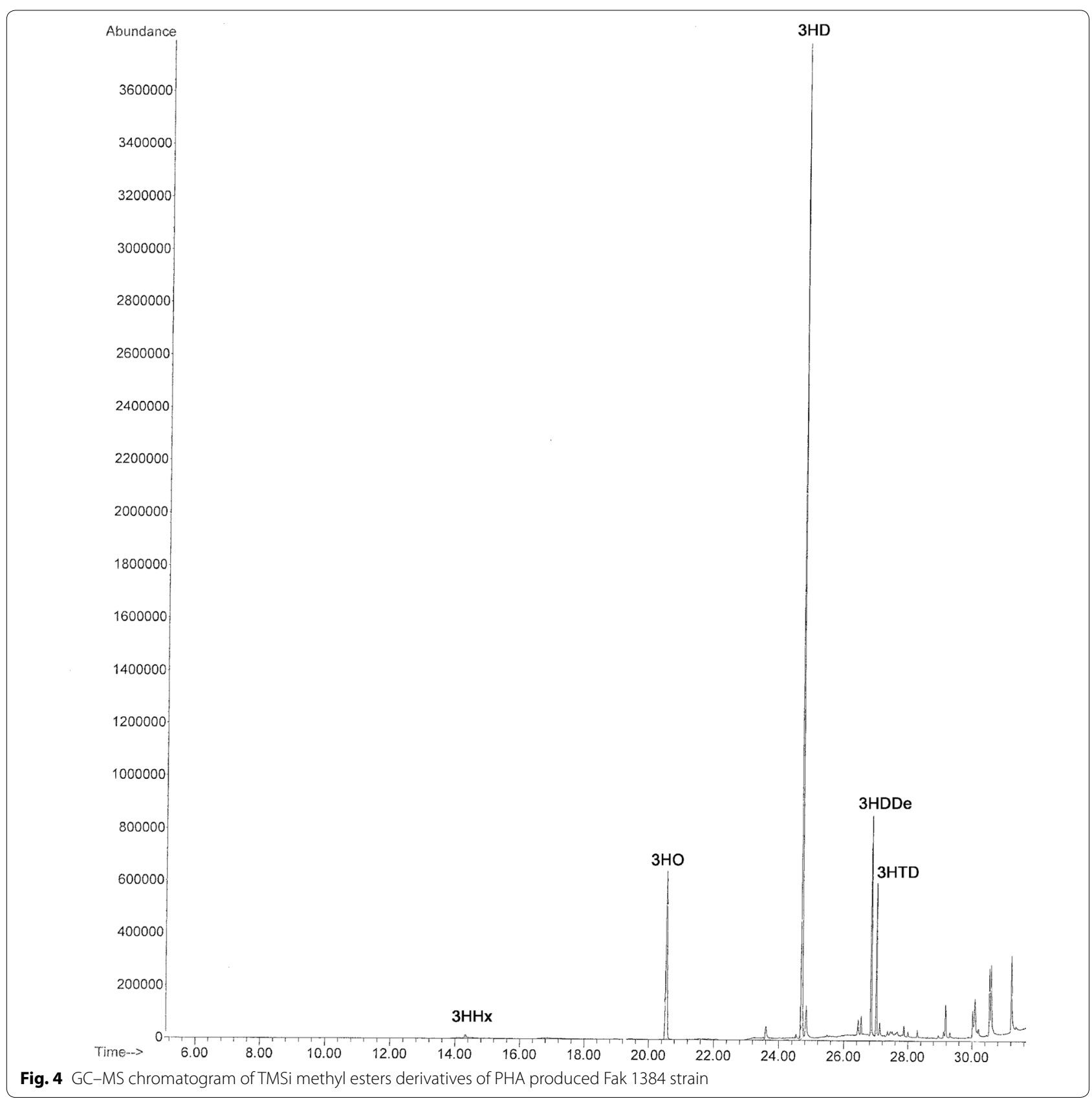




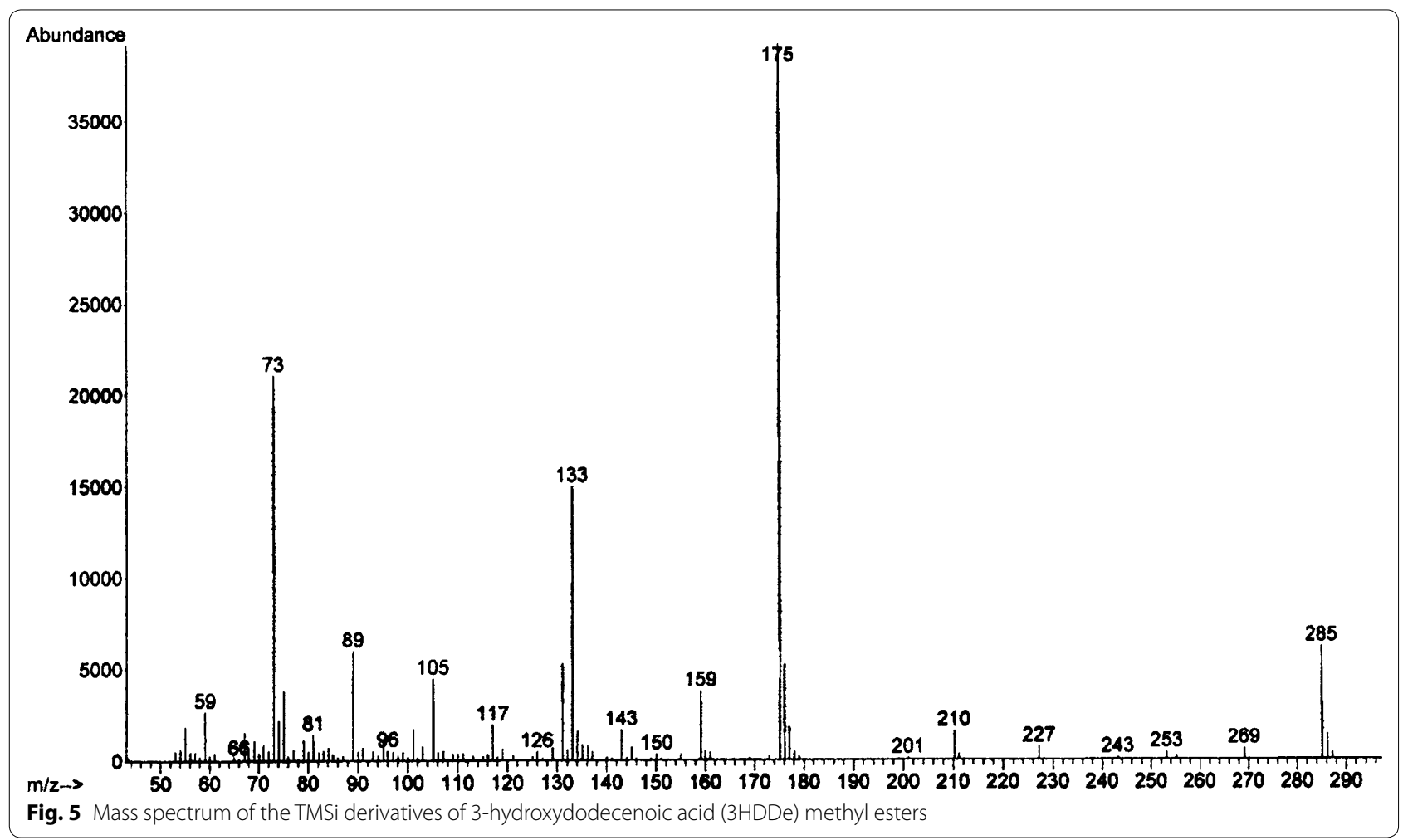

In conclusion, we used low-cost and efficient staining methods to screen over 760 isolates for PHA-producing bacteria from various marine environments. PHA production was demonstrated using coprah oil as a carbon source, which is cheaper than the usual carbon sources such as glucose or lactose. We found promising PHAproducing bacteria in all tested marine environments. However, a highlight is the isolate FAK 1384, as it is a mcl-PHA contains. The extraordinary properties make this mcl-PHA a good candidate for further exploitations in specialized fields of the industry, notably, for the biomedical area or in film and coating manufacturing.

\section{Additional file}

Additional file 1: Fig. S1. The multiple correspondence analysis performs a multivariate analysis, with categorical and quantitative variables. Two individuals are close to each other if they shared the same traits (variables). The green triangles show the presence or absence of PHA between the different associations. Isolates are shown in blue. MarSed: Marine sediment, MicroMat: Microbial mats, MarFilm: Marine film and MarAni: Marine animals. Fig. S2: The maximum-likelihood reconstruction of the 165 nuclear ribosomal DNA genotypes of Enterobacter shows the phylogenetic position of FAK1384 within the genera Enterobacter. Accession numbers are put in brackets. Node numbers indicate percentage bootstrap support from 500 replicates. Nodes without bootstrap values were supported by less than $75 \%$ of the replicates. Table S1: 25 out of the 70 tested isolates show a significant PHA production ability (>15\%).

\section{Authors' contributions}

PW carried out the microbial analysis, the sequencing and the phylogenetic analysis and draft the script. XM carried out the fermenter experiments and helped writing the script. CSC carried out the PHA characterisation. BC conceived the project and provided the library. VBL conceived, supervised the project and contributed to write the script. All authors read and approved the final manuscript.

\section{Author details}

1 LabEX Corail, USR3278 CNRS-EPHE-UPVD CRIOBE, BP1013, Papetoai, Moorea, French Polynesia. ${ }^{2}$ Pacific Biotech SAS, BP140289, Arue, Tahiti, French Polynesia. ${ }^{3}$ Laboratoire de Microbiologie des Environnements Extrêmes, LM2E, UMR6197 IFREMER-UBO-CNRS, BP 70, Plouzané, France.

\section{Acknowledgements}

The Project was funded by Tahiti Fa'ahotu, French Polynesia (PROPHA project), the «Contrat de projet Etat-Polynésie 2008-2013, and the CNRS, France. We would like to thank Dr. G. Lecellier for statistical advice and Dr. J. Guezennec for fruitful comments on the manuscript.

\section{Competing interests}

The authors declare that they have no competing interests.

Received: 16 September 2015 Accepted: 12 November 2015

Published online: 25 November 2015

\section{References}

Altschul SF, Gish W, Miller W, Myers EW, Lipman DJ (1990) Basic local alignment search tool. J Mol Biol 215:403-410

Arkin AH, Hazer B, Borcakli M (2000) Chlorination of poly (3-hydroxyalkanoates) containing unsaturated side chains. Macromolecules 33:3219-3223 
Arumugam A, Sandhya M, Ponnusami V (2014) Biohydrogen and polyhydroxyalkanoate co-production by Enterobacter aerogenes and Rhodobacter sphaeroides from Calophyllum inophyllum oil cake. Bioresour Technol 164:170-176

Arun A, Arthi R, Shanmugabalaji V, Eyini M (2009) Microbial production of poly-beta-hydroxybutyrate by marine microbes isolated from various marine environments. Bioresour Technol 100:2320-2323

Asrar J, D'haene P (1999) Modified polyhydroxyalkanoates for production of coatings and films. Patent WO 1999014268:A1

Bachere E, Guezennec J, Kouzayha A, Simon-Colin C (2011) Nucleus covered with PHA. Patent QO 2012080660

Chen Z, Li Y, Wen Q (2010) Isolation of a PHA producing strain with butyric acid as the carbon source and its shaking-flask fermentation character. Huan Jing Ke Xue 31:828-832

Chien C-C, Chen C-C, Choi M-H, Kung S-S, Wei Y-H (2007) Production of poly-beta-hydroxybutyrate (PHB) by Vibrio spp. isolated from marine environment. J Biotechnol 132:259-263

Dufresne AL, Reche RH, Lacroix M (2001) Gamma-ray crosslinking of poly93hydroxyoctanoate-co-undecenoate. Int J Biol Macromol 29:73-82

Ferrer M, Martínez-Abarca F, Golyshin P (2005) Mining genomes and "metagenomes" for novel catalysts. Curr Opin Biotechnol 16:588-593

González-García Y, Nungaray J, Córdova J, González-Reynoso O, Koller M, Atlic A, Braunegg G (2008) Biosynthesis and characterization of polyhydroxyalkanoates in the polysaccharide-degrading marine bacterium Saccharophagus degradans ATCC 43961. J Ind Microbiol Biotechnol 35:629-633

Guezennec J, Moppert X, Raguénès G, Richert L, Costa B, Simon-Colin C (2011) Microbial mats in French Polynesia and their biotechnological applications. Process Biochem 46:16-22

Hazer B, Steinbuechel A (2007) Increased diversification of polyhydroxylalkanoates by modification reactions for industrial and medical applications. Appl Microbiol Biotechnol 74:1-12

Imhoff JF, Labes A, Wiese J (2011) Bio-mining the microbial treasures of the ocean: new natural products. Biotechnol Adv 29:468-482

Jamil N, Ahmed N, Edwards DH (2007) Characterization of biopolymer produced by Pseudomonas sp. CMG607w of marine origin. J Gen Appl Microbiol 53:105-109

Kabilan S, Ayyasamy M, Jayavel S, Paramasamy G (2012) Pseudmonas sp. as a source of medium chain length polyhydroxyalkanoates for controlled drug delivery: perspective. Int J Microbiol

Kim Do Y, Kim H, Chung M, Rhee Y (2007) Biosynthesis, modification, and biodegradation of bacterial medium-chain-length polyhydroxyalkanoates. J Microbiol 45:87-97

Lozouet P, von Cosel R, Héros V, Le Goff A, Maestrati P, Menou J-L, Schiapapelli S, Trondlé J (2004) L'Atelier RAPA 2002 (Polynésie francaise). Xenophora 107:17-30

Madison LL, Huisman GW (1999) Metabolic engineering of poly(3-hydroxyalkanoates): from DNA to plastic. Microbiol Mol Biol Rev 63:21-53

McCliment EA, Nelson CE, Carlson CA, Witting J, Amaral-Zettler LA (2012) An all-taxon microbial inventory of the Moorea coral reef ecosystem. ISME J 6:309-319

Naheed N, Jamil N (2014) Optimization of biodegradable plastic production on sugar cane molasses in Enterobacter sp. SEL2. Braz J Microbiol Publ Braz Soc Microbiol 45:417-426

Numata K, Doi Y (2012) Doi Y Biosynthesis of polyhydroxyalkanaotes by a novel facultatively anaerobic Vibrio sp. under marine conditions. Mar Biotechnol NY N 14:323-331

Raguénès G, Moppert X, Richert L, Ratiskol J, Payri C, Costa B, Guezennec J (2004) A novel exopolymer-producing bacterium, Paracoccus zeaxanthinifaciens subsp. payriae, isolated from a "kopara" mat located in Rangiroa, an atoll of French Polynesia. Curr Microbiol 49:145-151

Rai R, Keshavarz T, Roether J, Boccaccini AR, Roy I (2011) Medium chain length polyhydroxylalkanoates, promising new biomedical materials for the future. Mater Sci Eng R Rep 72:29-47

Rawte T, Mavinkurve S (2002) Characterization of polyhydroxy alkanoatesbiodegradable plastics from marine bacteria. Curr Sci 83:562-564
Richert L, Golubic S, Guédès RL, Ratiskol J, Payri C, Guezennec J (2005) Characterization of exopolysaccharides produced by Cyanobacteria isolated from polynesian microbial mats. Curr Microbiol 51:379-384

Samrot AV, Avinesh RB, Sukeetha SD, Senthilkumar P (2011) Accumulation of poly[(R)-3-hydroxyalkanoates] in Enterobacter cloacae SU-1 during growth with two different carbon sources in batch culture. Appl Biochem Biotechnol 163:195-203

Sawant SS, Salunke BK, Kim BS (2014) A laboratory case study of efficient polyhydoxyalkonates production by Bacillus cereus, a contaminant in Saccharophagus degradans ATCC 43961 in minimal sea salt media. Curr Microbiol 69:832-838

Schlegel HG, Lafferty R, Krauss I (1970) The isolation of mutants not accumulating poly-beta-hydroxybutyric acid. Arch Für Mikrobiol 71:283-294

Shrivastav A, Mishra SK, Mishra S (2010a) Polyhydroxyalkanoate (PHA) synthesis by Spirulina subsalsa from Gujarat coast of India. Int J Biol Macromol 46:255-260

Shrivastav A, Mishra SK, Shethia B, Pancha I, Jain D, Mishra S (2010b) Isolation of promising bacterial strains from soil and marine environment for polyhydroxyalkanoates (PHAs) production utilizing Jatropha biodiesel byproduct. Int J Biol Macromol 47:283-287

Simon-Colin C, Alain K, Colin S, Cozien J, Costa B, Guezennec JG, Raguénès GHC (2008a) A novel mcl PHA-producing bacterium, Pseudomonas guezennei sp. nov., isolated from a "kopara" mat located in Rangiroa, an atoll of French Polynesia. J Appl Microbiol 104:581-586

Simon-Colin C, Raguénès G, Costa B, Guezennec J (2008b) Biosynthesis of medium chain length poly-3-hydroxyalkanoates by Pseudomonas guezennei from various carbon sources. React Funct Polym 68:1534-1541

Simon-Colin C, Raguénès G, Crassous P, Moppert X, Guezennec JG (2008c) A novel mcl-PHA produced on coprah oil by Pseudomonas guezennei biovar. tikehau, isolated from a "kopara" mat of French Polynesia. Int J Biol Macromol 43:176-181

Simon-Colin C, Alain K, Raguénès G, Schmitt S, Kervarec N, Gouin C, Crassous P, Costa B, Guezennec JG (2009) Biosynthesis of medium chain length poly (3-hydroxyalkanoates) (mcl PHAs) from cosmetic co-products by Pseudomonas raguenesii sp. nov., isolated from Tetiaroa, French Polynesia. Bioresour Technol 100:6033-6039

Solaiman DKY, Ashby RD, Foglia TA (2000) Rapid and specific identification of medium-chain-length polyhydroxyalkanoate synthase gene by polymerase chain reaction. Appl Microbiol Biotechnol 53:690-694

Spiekermann P, Rehm BH, Kalscheuer R, Baumeister D, Steinbüchel A (1999) A sensitive, viable-colony staining method using Nile red for direct screening of bacteria that accumulate polyhydroxyalkanoic acids and other lipid storage compounds. Arch Microbiol 171:73-80

Tamura K, Peterson D, Peterson N, Stecher G, Nei M, Kumar S (2011) MEGA5: molecular evolutionary genetics analysis using maximum likelihood, evolutionary distance, and maximum parsimony methods. Mol Biol Evol 28:2731-2739

Verlinden R, Hill D, Kenward M, Williams C, Radecka I (2007) Bacterial synthesis of biodegradable polyhydroxylalkanoates. J Appl Microbiol 102:1437-1449

\section{Submit your manuscript to a SpringerOpen ${ }^{\circ}$ journal and benefit from:}

- Convenient online submission

- Rigorous peer review

- Immediate publication on acceptance

- Open access: articles freely available online

- High visibility within the field

- Retaining the copyright to your article

Submit your next manuscript at $>$ springeropen.com 